\title{
Technology Advancement : Implementation of Real Time Mode in Higher Education Examination System
}

\author{
Pravin Pandit Shinkar ${ }^{1}$, Dr. Bechoo Lal ${ }^{2}$ \\ ${ }^{1}$ Research Scholar, Department of Computer Science, SJJT University, Jhunjhunu, Rajasthani, India \\ ${ }^{2}$ Assistant Professor, Department of Information Technology, Western College, University of Mumbai, India
}

\begin{abstract}
In this research article the researcher emphasized thetas move into the 21st century, many factors are bringing strong forces to bear on the adoption of ICTs in education and contemporary trends suggest will soon see large scale changes in the way education is planned and delivered as a consequence of the opportunities and affordances of ICT. It is believed that the use of ICT in education can increase access to learning opportunities. It can help to enhance the quality of education with advanced teaching methods, improve learning outcomes and enable reform or better management of education systems. By employing ICT in teacher training can save a lot of money of the Government. Moreover a lot of qualitative improvement can be seen as resource persons for the training can be best of the world. By employing ICT in administration can help in solving the problem of Absenteeism of students and teachers. Good quality content is one of the major issue and directly affects the standards of education and quality. By overcoming the certain challenges involved in the process of education can help a lot in this side. Conclusively a lot of quality improvement is possible after careful and planned implementation of ICT in education examination System with the help of real time mode.
\end{abstract}

Keywords : ICT, Real Time, Education System

\section{INTRODUCTION}

Information and communication technology is playing crucial role in the higher education. ICT has become an integral part of everyday life for many people. It is expected that the trend will continue in increasing the importance of ICT in people's lives and, to the extent that ICT literacy will become a functional requirement for personal lives, work and social life. These are directly influencing the way human beings are engaging themselves in their routine activities. The socio-economic environment needs a catalyst to bring social change in the human development. Large scale deployment of communications technologies has produced major changes in the way we communicate for social and business purposes and most of these deployments are technology-led. The internet, television, mobile phones, computer-based devices and other new forms of information technology are changing rapidly and are also influencing the social life. ICT applications can support sustainable development, in the fields of public administration, business, education and training, health, employment, environment, agriculture and science.

The development and use of technology has greatly improved our lives. We are dependent on technologies to accomplish specific tasks in our lives. With the use of various emerging technology life has become very comfortable. Technology is being implemented in almost every segment of our lives and 
businesses. We can book tickets of shows, book railway, bus or flight tickets, purchase or sale products, pay bills at our comforts sitting at home without. ATMs are used to withdraw money any time and much more applications. All these processes are carried out with the help of technology.

ICT covers all the technological tools to process and communicate information. It includes two aspects of information technology and communication technology. Information technology encompasses all matters relating to the acquisition, manipulation, and management of information. Communication technology encompasses all the matters to the transfer and sharing of information.

Examinations play an important role in imparting education and knowledge to students. Examination is an instrument to evaluate the knowledge, understanding and learning of studens.For teachers, Examinations provides feedback their way of teaching. In the last couple of decades, higher education has witnessed tremendous growth in terms of number of students enrolled, number of courses offered, and number of affiliated colleges etc. As a result of this growth, the examination system at universities quite complex and complicated.

In Maharashtra, serious concerns have been expressed on various allegations regarding leakage of university examination papers and negative image being portrayed by the media about the capabilities of Universities to hold \& organize examinations in a fair manner. ICT is playing crucial role to resolve issue. On line paper delivery system sends the question paper 45 minutes prior to examinations. This is reliable system and university can conduct examination smoothly. There is scope to improve the system from online to real time mode.

\section{BACKGROUND OF THE RESEARCH STUDY}

[1] J. Enrique Hinostroza, Christian Labbé \& Magdalena Claro (Oct. 2005) Regarding the location of computers, the fact that the majority of the computers in primary and secondary schools are located in the computer labs is mainly due to the ICT in Education policy in Chile. This program provided computer labs to schools without the possibility of installing these computers in the classrooms. Therefore, the fact that some secondary schools do have a few computers in the classrooms is due to their own initiative. These results support the assumption that the majority of students' and teachers' ICTrelated activities are carried out in the computer lab. Additionally, the relatively high percentage of schools connected to Internet enables ICT-related activities and use of Internet resources.

[2].Khalid Abdullah Bingimlas((2009) The aim of this paper was to provide information on encouraging the desired improvement in the future teaching situation to those responsible for the integration of ICT into science education. The findings of this study indicate that teachers have a strong desire for the integration of ICT into education but that they encountered many barriers to it. The major barriers were lack of confidence, Lack of competence and lack of access to resources.

[3]. Steve U. Basse, Diepreye Okodoko\&Uduak D. Akpanumoh(April 2009) it was an attempt to explain the crucial role that ICT can play in the effective management of higher education for sustainable development in the developing countries of Africa in the 21st century. Specifically, the paper analyzed the variables ICTs in university teaching, learning, research, administration and challenges of massive application of ICTs in African universities. 
[4]M Wasif Nisar, Ehsan Ullah munir and shafqat Ali shad (2011) The major finding of this paper is that availability and usage of ICT is very essential to improve the educational efficiency of students' and. After analyzing all the results we conclude that ICT brings a positive impact on education sector of Pakistan.

[5] Zafar Ahmed SHAIKH \& Shakeel Ahmed KHOJA (January 2011) This study adds rigor in ICT policy and planning, administration, and integration at the higher education level and affirms that an effective and robust ICT policy for HES can change the current status of Pakistan as poor in terms of a knowledgebased economy to rich. The recommendations and empirical evidence collected from this study are important contributions to the literature.

[6] Charles Musarurwa (2011) the major challenges facing the integration of ICT into the teacher education curriculum in Zimbabwe are sustainability and replication. Firstly, it was an external partner who managed to identify the gap that existed within the higher education sector, particularly within teacher education, that there was a need to provide both ICT resources and skills. Yet, teacher education colleges should have been treated as the nerve centre of the whole computerization programmer.

Secondly, although the CITEP programme remains one of the most tangible and successful programme yet in the history of teacher education in Zimbabwe, it still remains too little and too late. It can be described as a trial or pilot programmed, since it operated in three secondary teacher education colleges only. The other 12 colleges were not involved and will need to undergo the same development. Taking into account that it was an external partner who identified the knowledge and resource gap and funded the programme, then it may be an uphill task for the other colleges to develop to the same level, since the external partner is now involved in other programmes. If both the Ministry of Higher and Tertiary Education and the remaining colleges work hand.

[7] Ajit Mondal \& Dr. Jayanta Mete (2012)

The four most common mistakes in introducing ICTs into teaching are I) installing learning technology without reviewing student needs and content availability; ii) imposing technological systems from the top down without involving faculty and students; iii) using inappropriate content from other regions of the world without customizing it appropriately; and iv) producing low quality content that has poor instructional design and is not adapted to the technology.

[8] Sukanta Sarkar(May 2012) Extrapolating current activities and practices, the continued use and development of ICTs within education will have a strong impact on: What is learned, how it is learned, when and where learning takes place, \& who is learning and who is teaching. The continued and increased use of ICTs in education in years to come, will serve to increase the temporal and geographical opportunities that are currently experienced. The integration of ICTs in higher education is inevitable. The very high demand for higher education has stimulated significant growth in both private and public provision. ICTs in the form of Management Information Systems are increasingly universal. The strength of computers in teaching is their power to manipulate words and symbols - which is at the heart of the academic endeavor. ICT has also led to the emergence of Open Educational Resources (OERs).

[9].Sharmila Devi, Mohammad Rizwaan\&Subhash Chander (June 2012) Paper deals with Quality education through ICT and its awareness among stakeholders will have positive impact on the society. ICT can be helpful in quality and standards of education by implementing it in various phases of 
education. ICT can be employed in formal and Nonformal types of education and would eventually make the learners employable and socially useful part of the society. by various stakeholders.

[10] Alexander Aristovnik (July 2012)The empirical results also suggest that, in general, some less developed EU countries such as Slovakia and Poland show a relatively high level of ICT efficiency due to the low level of their ICT inputs. Therefore, a significant increase in ICT expenditures is needed in those countries. All in all, the analysis finds evidence that most of the countries under consideration hold great potential for increased efficiency in ICT and for improving their educational outputs and outcomes.

\section{STATEMENT OF PROBLEM \& NEED OF RESEARCH}

ICT is playing important role in higher education. Impact of ICT is not only limited to Teaching \&

\section{FRAMEWORK OF PROPOSED RESEARCH STUDY}

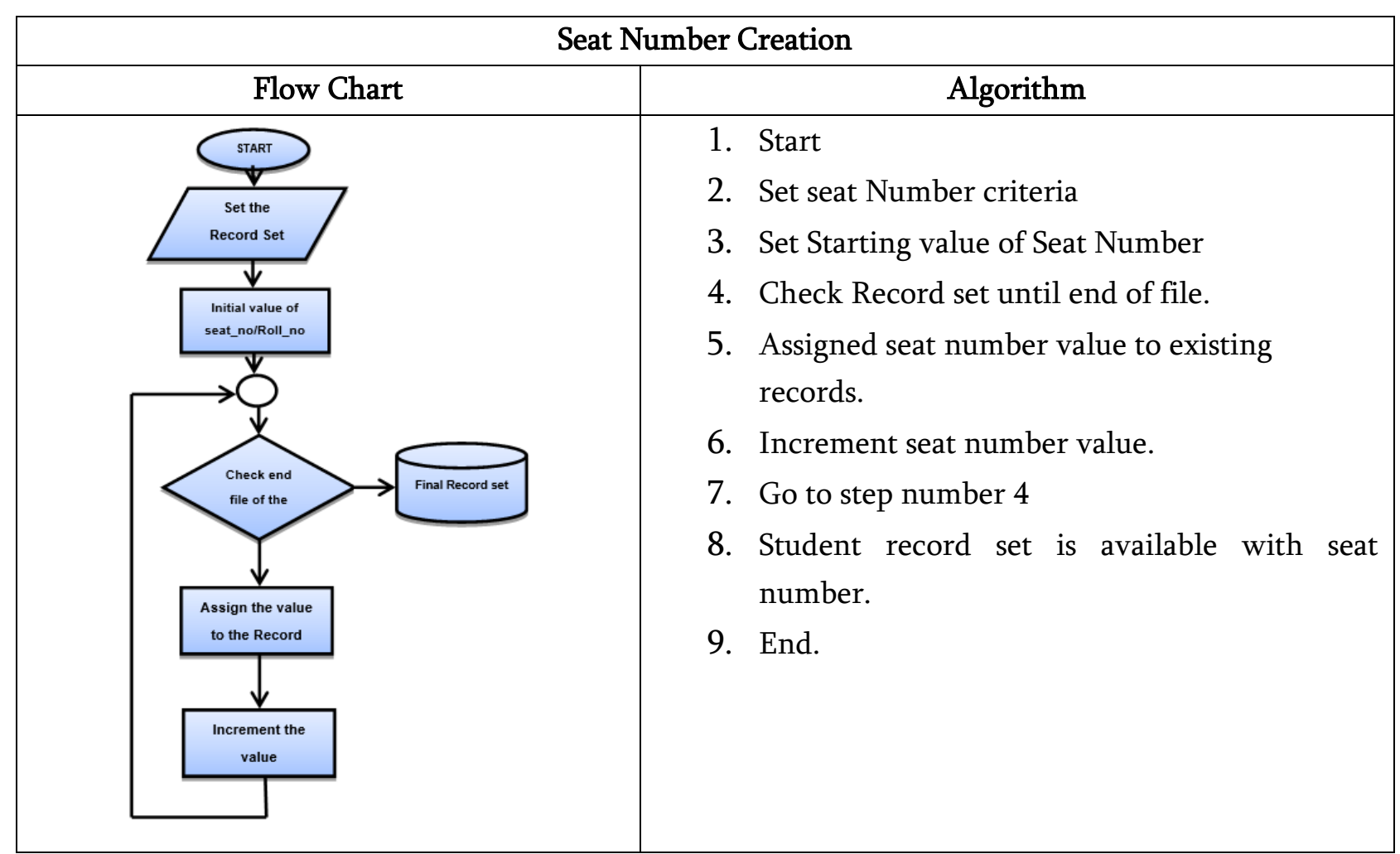

Learning methods but also various services to students in higher education. Whatever services students are getting are not getting on time. Currently University of Mumbai is working on online and offline mode. The university examination system is changing at a dramatic rate. There are multiple processes going on within the examination system Improving the efficiency of examination systems is one of the most challenging goals of today's society. There is need of research work in higher education to overcome all issues and deliver quality services to all stakeholders of university.

\section{OBJECTIVES OF THE RESEARCH}

1. To Study the secured examination system

2. To develop a new effective \& efficient model for examination system

3. Analysis and Evaluation of proposed model 


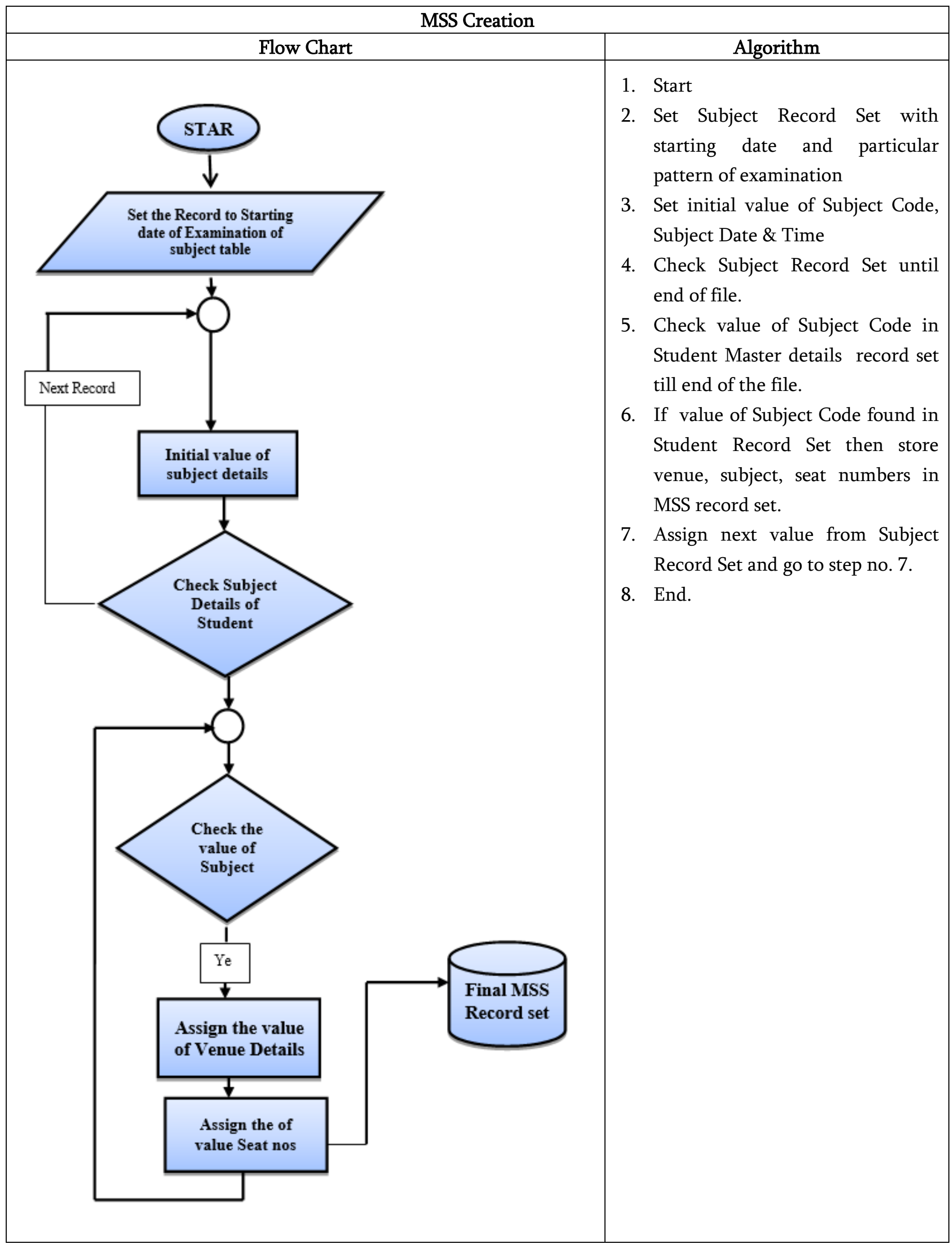




\section{MSS Printing}

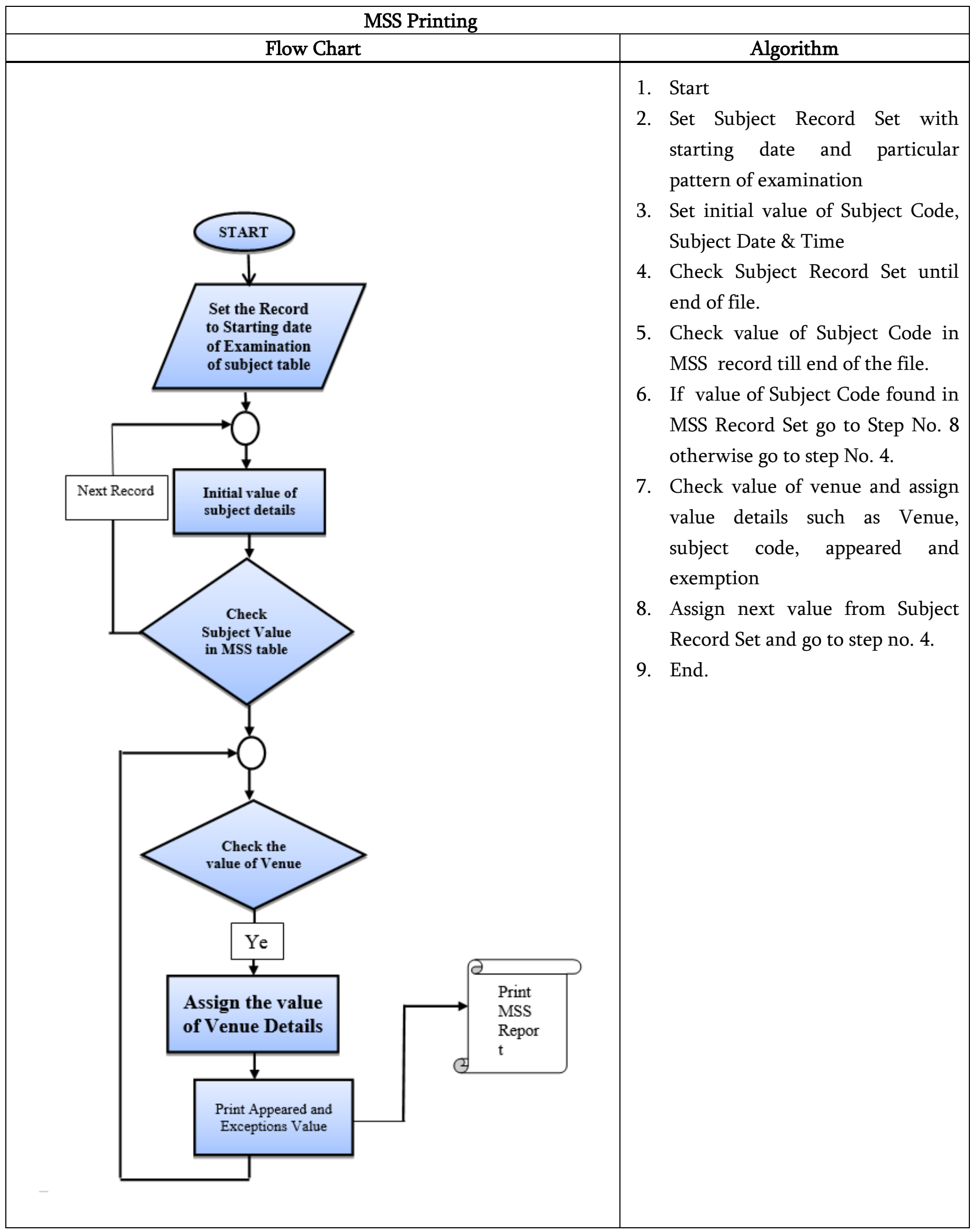




\section{RESULTS AND DISCUSSION}

\section{RESULTS}

Analysis Before Seat Number Generation

\begin{tabular}{|c|c|c|c|c|c|c|c|c|}
\hline COLL_NO & NAME & SEX & CENT_NO & PP1 & PP2 & PP3 & PP4 & PP5 \\
\hline 100010 & ABCD & 1 & 10 & 1 & 2 & 3 & 5 & 12 \\
\hline 100010 & ABCD & 1 & 10 & 1 & 2 & 3 & 5 & 12 \\
\hline 100010 & $\mathrm{ABCD}$ & 1 & 10 & 1 & 2 & 3 & 5 & 12 \\
\hline 100010 & $A B C D$ & 1 & 10 & 1 & 2 & 3 & 5 & 12 \\
\hline 1000523 & $\mathrm{ABCD}$ & 1 & 523 & 1 & 2 & 3 & 6 & 8 \\
\hline 1000523 & $\mathrm{ABCD}$ & 1 & 523 & 1 & 2 & 3 & 6 & 8 \\
\hline 1000523 & ABCD & 1 & 523 & 1 & 2 & 3 & 6 & 8 \\
\hline 1000523 & ABCD & 1 & 523 & 1 & 2 & 3 & 6 & 8 \\
\hline 1000523 & $\mathrm{ABCD}$ & 1 & 523 & 1 & 2 & 3 & 6 & 8 \\
\hline 1000561 & ABCD & 1 & 561 & 1 & 2 & 3 & 5 & 10 \\
\hline 1000561 & ABCD & 1 & 561 & 1 & 2 & 3 & 5 & 12 \\
\hline 1000561 & ABCD & 1 & 561 & 1 & 2 & 3 & 5 & 12 \\
\hline 1000561 & $\mathrm{ABCD}$ & 1 & 561 & 1 & 2 & 3 & 5 & 12 \\
\hline 1000561 & $\mathrm{ABCD}$ & 1 & 561 & 1 & 2 & 3 & 5 & 12 \\
\hline 1000692 & $\mathrm{ABCD}$ & 1 & 692 & 1 & 2 & 3 & 6 & 13 \\
\hline 1000692 & ABCD & 1 & 692 & 1 & 2 & 3 & 6 & 13 \\
\hline 1000692 & $\mathrm{ABCD}$ & 1 & 692 & 1 & 2 & 3 & 6 & 13 \\
\hline 1000692 & $\mathrm{ABCD}$ & 1 & 692 & 1 & 2 & 3 & 6 & 13 \\
\hline 1000692 & ABCD & 1 & 692 & 1 & 2 & 3 & 6 & 13 \\
\hline 1000802 & ABCD & 1 & 802 & 1 & 2 & 3 & 6 & 12 \\
\hline 1000802 & $\mathrm{ABCD}$ & 1 & 802 & 1 & 2 & 3 & 6 & 12 \\
\hline 1000802 & $\mathrm{ABCD}$ & 1 & 802 & 1 & 2 & 3 & 6 & 12 \\
\hline 1000802 & $\mathrm{ABCD}$ & 1 & 802 & 1 & 2 & 3 & 6 & 12 \\
\hline 1000802 & $\mathrm{ABCD}$ & 1 & 802 & 1 & 2 & 3 & 6 & 12 \\
\hline 1000822 & $\mathrm{ABCD}$ & 1 & 822 & 1 & 2 & 3 & 6 & 13 \\
\hline 1000822 & $\mathrm{ABCD}$ & 1 & 822 & 1 & 2 & 3 & 6 & 13 \\
\hline 1000822 & ABCD & 1 & 822 & 1 & 2 & 3 & 6 & 13 \\
\hline 1000822 & ABCD & 1 & 822 & 1 & 2 & 3 & 6 & 14 \\
\hline 1000822 & ABCD & 1 & 822 & 1 & 2 & 3 & 6 & 14 \\
\hline 1000948 & ABCD & 1 & 948 & 1 & 2 & 3 & 6 & 12 \\
\hline 1000948 & ABCD & 1 & 948 & 1 & 2 & 3 & 6 & 12 \\
\hline 1000948 & ABCD & 1 & 948 & 1 & 2 & 3 & 6 & 12 \\
\hline 1000948 & $\mathrm{ABCD}$ & 1 & 948 & 1 & 2 & 3 & 6 & 12 \\
\hline 1000948 & $\mathrm{ABCD}$ & 1 & 948 & 1 & 2 & 3 & 6 & 12 \\
\hline
\end{tabular}


Analysis After seat Number Generation

\begin{tabular}{|c|c|c|c|c|c|c|c|c|c|}
\hline $\begin{array}{l}\text { COLL_N } \\
\mathrm{O}\end{array}$ & NAME & SEX & $\begin{array}{l}\text { CENT_N } \\
\mathrm{O}\end{array}$ & PP1 & PP2 & PP3 & PP4 & PP5 & $\begin{array}{l}\text { SEAT_N } \\
\mathrm{O}\end{array}$ \\
\hline 100010 & ABCD & 1 & 10 & 1 & 2 & 3 & 5 & 12 & 2270001 \\
\hline 100010 & $A B C D$ & 1 & 10 & 1 & 2 & 3 & 5 & 12 & 2270002 \\
\hline 100010 & ABCD & 1 & 10 & 1 & 2 & 3 & 5 & 12 & 2270003 \\
\hline 100010 & ABCD & 1 & 10 & 1 & 2 & 3 & 5 & 12 & 2270004 \\
\hline 1000523 & ABCD & 1 & 523 & 1 & 2 & 3 & 6 & 8 & 2270070 \\
\hline 1000523 & $\mathrm{ABCD}$ & 1 & 523 & 1 & 2 & 3 & 6 & 8 & 2270071 \\
\hline 1000523 & $\mathrm{ABCD}$ & 1 & 523 & 1 & 2 & 3 & 6 & 8 & 2270072 \\
\hline 1000523 & ABCD & 1 & 523 & 1 & 2 & 3 & 6 & 8 & 2270073 \\
\hline 1000523 & ABCD & 1 & 523 & 1 & 2 & 3 & 6 & 8 & 2270074 \\
\hline 1000561 & $\mathrm{ABCD}$ & 1 & 561 & 1 & 2 & 3 & 5 & 10 & 2270125 \\
\hline 1000561 & ABCD & 1 & 561 & 1 & 2 & 3 & 5 & 12 & 2270126 \\
\hline 1000561 & $\mathrm{ABCD}$ & 1 & 561 & 1 & 2 & 3 & 5 & 12 & 2270127 \\
\hline 1000561 & $\mathrm{ABCD}$ & 1 & 561 & 1 & 2 & 3 & 5 & 12 & 2270128 \\
\hline 1000561 & $\mathrm{ABCD}$ & 1 & 561 & 1 & 2 & 3 & 5 & 12 & 2270129 \\
\hline 1000692 & $\mathrm{ABCD}$ & 1 & 692 & 1 & 2 & 3 & 6 & 13 & 2270194 \\
\hline 1000692 & $\mathrm{ABCD}$ & 1 & 692 & 1 & 2 & 3 & 6 & 13 & 2270195 \\
\hline 1000692 & $\mathrm{ABCD}$ & 1 & 692 & 1 & 2 & 3 & 6 & 13 & 2270196 \\
\hline 1000692 & ABCD & 1 & 692 & 1 & 2 & 3 & 6 & 13 & 2270197 \\
\hline 1000692 & ABCD & 1 & 692 & 1 & 2 & 3 & 6 & 13 & 2270198 \\
\hline 1000802 & ABCD & 1 & 802 & 1 & 2 & 3 & 6 & 12 & 2270264 \\
\hline 1000802 & $\mathrm{ABCD}$ & 1 & 802 & 1 & 2 & 3 & 6 & 12 & 2270265 \\
\hline 1000802 & $\mathrm{ABCD}$ & 1 & 802 & 1 & 2 & 3 & 6 & 12 & 2270266 \\
\hline 1000802 & $\mathrm{ABCD}$ & 1 & 802 & 1 & 2 & 3 & 6 & 12 & 2270267 \\
\hline 1000802 & ABCD & 1 & 802 & 1 & 2 & 3 & 6 & 12 & 2270268 \\
\hline
\end{tabular}

\section{DISCUSSIONS}

1. The research emphasized that the above system generated report is representing coursewise / datewise / venuewise report. For getting this report system is getting input from subjects of particular course and their details like date and time. The internal mechanism is completed by different program segment with respect to their process. First level contains to generate seat numbers .second level contains subject offered by candidates and third level contains name of the candidates. During this process researcher found that various examination system automatically accepted all input data from course master, subject master and college master.

For the instances in real time mode the university examination systems the clusters are generated with 
respective college location and center offered by candidates.

In addition to this report is also capable to check cross verification paper availability and their respective pattern like credit base choice base, credit base semester grading system and various another pattern.

The system is also capable to generate number of candidates are appeared in their respective pattern and subjects. This will help to colleges/Institutes and university department for their distribution of answer books and question paper

At this stage researcher is thinking to generate barcode and their respective venues of examination dynamically. This will help to college and university. for this operation the researcher suggested that one more hardware device has to be installed at all venues of examination. The device will generate barcode of candidate based on course, pattern of examination, subject details and date time of examination. This will help to university examination system from wrong handwritten numbers written by candidates. University examination system in real time will help to university to early declaration of results.

2. The report generated through system is known as subject wise venue wise list. It is also known as expansion of question paper delivery report.

This real time system report consist of details of seat no which are appearing in current semester with course details.

Course details consist of name of subject, name of course, date of examination, time of examination, venue of examination, seat numbers and total number of students.
The expectation of this process means the number of answer book should be equal to number of bar codes used by university examination system.

The researcher found that if course wise / subject wise answer book not equal to number of bar code used by venue for particular course and subject. The system will automatically intimate to college principal as well as University authority to resolve the issue.

3. The report analysis generated through system is venue wise/ subject wise list Different parameters used in this report such as seat number, venue number, name of venue, seat no, date of examination, time of examination.

The researcher found that university examination system will allocate list of the venues to the colleges after assignment of seat no and particular venue to the student.

This report will help to college / Institutes / university department to count and verify number of answer book with bar code generated by system. It is also useful for seating arrangement can decide from number of students as well as blocks (number of rooms) seating arrangement to conduct the smooth examination.

Principal can allocate the examination work well in advance and give the instructions to the teaching and non-teaching staff for smooth conduct of examination. We can send the mail to the principal in real time mode.

\section{SCOPE OF THE RESEARCH STUDY}

1. Reduced process Time

2. Secured Examination

3. Minimum manual Intervention

4. Reduced malpractice. 

5. Higher efficiency
6. Reliability
7. Extension of application to University of Mumbai
Limitation of the Research
1. Limitation to examination - system
2. Data Specification constraints.

\section{CONCLUSION}

Finally, the researcher concluded that there are different parameters used in this report such as seat number, venue number, name of venue, seat no, date of examination, time of examination. The researcher found that university examination system will allocate list of the venues to the colleges after assignment of seat no and particular venue to the student. This report will help to college / Institutes / university department to count and verify number of answer book with bar code generated by system. It is also useful for seating arrangement can decide from number of students as well as blocks (number of rooms) seating arrangement to conduct the smooth examination. In this research article the researcher emphasized and proposed a research study to implement real time mode to control university examination system with the help of ICT to improve computational efficiency and instant response to the colleges and students about their results status.

\section{REFERENCES}

[1]. J. Enrique Hinostroza, Christian Labbe \& Magdalena Claro, and ICT in Chilean school: Students and teachers access to and use of ICT, ISSN: 1795-6889, Volume 1 (2), 246-264, October 2005

[2]. Khalid Abdullah Bingimlas((2009), Barrier to the successful integration of ICT in Teaching and Learning environments, ISSN 1305-8223, 5(3),235-245 , Year 2009
[3]. Steve U. Basse, Diepreye Okodoko\&Uduak D. Akpanumoh (April 2009), Information Communication Technologies in the Management of Education for Sustainable Development in Africa, ISSN 1994-9057 (Print) ISSN 2070-0083 (Online) Vol. 3 (3), April, 2009

[4]. M Wasif Nisar, Ehsan Ullah munir and shafqat Ali shad, Usage and impact of ICT in Education sector: A Study of Pakistanis' 1991-8178 Volume 5(12), 578-583, 2011

[5]. Zafar Ahmed SHAIKH \& Shakeel Ahmed KHOJA, Role of ICT in shaping the future of Pakistani higher education system, TOJET: The Turkish Online Journal of Educational Technology - volume 10 Issue 1, January 2011

[6]. Charles Musarurwa, Teaching With and Learning through ICTs in Zimbabwe's Teacher Education Colleges, ISSN 1548-6613, A 7 952959,2011

[7]. Ajit Mondal \& Dr. Jayanta Mete, ICT in Higher Education: Opportunities and Challenges, (ISSN 2249-3301), Vol. II, 2012.

[8]. Sukanta Sarkar, The Role of Information and Communication Technology (ICT) in Higher Education for the 21st Century, ISSN 2277 9566, Vol. 1 No. 1 Page No- 30-40, (May 2012)

[9]. Sharmila Devi, Mohammad Rizwaan\&Subhash Chander, ICT for Quality of Education in India, ISSN: 2249-5894 Volume 2, Issue 6 June 2012

[10]. Alexander Aristovnik, The impact of ICT on educational performance and its efficiency in EU and OECD countries: a Non Parametric analysis, volume 11 Issue 3, July 2012

[11]. Paul P.K. and Mondal N.K.,Integration of ICT in School Education: An Analytical Study in Burdwan District in West Bengal, India, ISSN 2319-1171, Vol. 1(4), 21-25, November (2012)

[12]. Meenakshi, Importance of ICT education, ISSN: 2320-7388, p-ISSN 2320-737X Volume I Issue 4 (May-Jun 2013) PP 03-08 
[13]. Nana Yaw Sabered, Hamelin Mohammed Ahmed, Towards Enhancing Quality in Education through Information and Communication Technologies (ICTs) in Higher Educational Institutions (HEIs), International Journal of Computer Applications (0975 - 8887)

Volume 62- No.8, January 2013

[14]. Jo Shan Fu, a Critical Literature Review and Its Implication, (IJEDICT), Vol. 9, Issue 1, pp. 112125, 2013,

[15]. Vimbai Edina Ndawi, Kennedy Andrew Thomas\& Tendayi Leonorah yaruwata, Barriers to Effective Integration of Information and Communication Technology in Harare Secondary Schools, ISSN: 2319-7064 Volume 2 Issue 9, September 2013

[16]. Munienge Mbodila, Telisa Jones, Kikunga Muhandji (Nov. 2013). Integration of ICT in Education: Key Challenges ISSN 2250-2459, Volume 3, Issue 11, November 2013)

[17]. Uttam $\mathrm{Kr}$ Pegu (2014). Information and Communication Technology in Higher,Education in India: Challenges and Opportunities, Volume 4, Number 5 (2014), pp. 513-518

[18]. Jota Narayan Patra((June 2014), The Role of ICT in improving the Quality of School Education in India, ISSN 2277-2456, Volume-III, Issue-II, Apr-May-June 2014

[19]. Rajeev Puri, Cloud Computing in Education and Sports in India, ISSN: 2229-6913, Issue, Vol. 10, and June 2014

[20]. Brijendra Singh Yadav \& Ajay Poddar, ICT At University level management education -one step forward in shaping right human resource of tomorrows india, ISSN: 2348-3083. VOL. I/IV, June-July 2014

[21]. Kofi Bentum Wilson, Isaac Tete-Mensah, Kofi Agyenim Boateng (July 2014). Information and communication technology use in higher education perspectives from student's vol.10, No.19 ISSN: 1857 - 7881.

\section{Cite this article as :}

Pravin Pandit Shinkar, Dr. Bechoo Lal, "Technology Advancement : Implementation of Real Time Mode in Higher Education Examination System", International Journal of Scientific Research in Science and Technology (IJSRST), Online ISSN : 2395-602X, Print ISSN : 2395-6011, Volume 6 Issue 6, pp. 317-327, November-December 2019. Available at doi : https://doi.org/10.32628/IJSRST119662 Journal URL : http://ijsrst.com/IJSRST119662 